Pamiętnik Literacki 2020, 1, s. 111-124

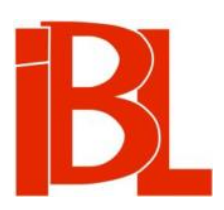

\title{
Metaforyka żywiołów w liryce Franciszka Dionizego Kniaźnina
}

Bożena Mazurkowa 
Pamiętnik Literacki CXI, 2020, z. 1, PL ISSN 0031-0514

DOI: $10.18318 / \mathrm{pl} .2020 .1 .7$

BOŻENA MAZURKOWA Uniwersytet Śląski, Katowice

\section{METAFORYKA ŹYWIOŁÓW W LIRYCE FRANCISZKA DIONIZEGO KNIAŹNINA}

Sięgajace tradycji antycznej zainteresowanie metafora ${ }^{1}$, jej odmianami i zasadami konstrukcji, doborem współtworzących ją elementów i obrazów, funkcjami pozaliterackimi oraz rolą w organizacji materii poetyckiej, w określaniu horyzontów wyobraźni, a tym samym specyfiki warsztatu dawnych i współczesnych poetów od lat przyciaga uwagę badaczy i jest żywe również w rodzimych studiach o charakterze teoretycznym, oraz (w szerszym wymiarze) w dociekaniach analityczno-interpretacyjnych $^{2}$. Zjawisko to potwierdzają także najnowsze publikacje $-z$ ostatniej dekady. Jak podkreśla Marek Stanisz w książce poświęconej metaforyce refleksji polskich romantyków nad poezją:

Gigantyczna literatura przedmiotu na ten temat, obejmująca prace z zakresu językoznawstwa, teorii komunikacji i literaturoznawstwa, jak również z obszarów historii, psychologii i filozofii, historii sztuki i filmu, historii nauki, a nawet prawa, dowodzi niezbicie, że wiedza o metaforze dawno przestała być kwestią wąsko pojętej stylistyki, stając się jednym z centralnych zagadnień współczesnych badań humanistycznych ${ }^{3}$.

We wskazanym typie studiów przedmiotem obserwacji wielokrotnie w różnym zakresie był twórczy dorobek naszych rodzimych literatów doby stanisławowskiej, w tym również szczególny, interesujący nas typ metafory, która wykorzystuje odwołania do czterech podstawowych elementów wszechświata ${ }^{4}$ Kilka razy podejmo-

1 Zob. Ary s t o tele s, Poetyka. W: Retoryka. Poetyka. Przekł., wstęp i komentarz H. P o d b i els ki. Warszawa 1988, s. 251.

2 Zob. m.in. prace zgromadzone w dwóch monograficznych tomach, $\mathrm{z}$ których pierwszy w większym zakresie ma charakter analityczno-interpretacyjny, natomiast drugi - głównie teoretyczny: Studia o metaforze. 1. Red. E. Sarnow s ka-Tem erius z. Wrocław 1980. - Studia o metaforze. 2. Red. M. Głowiński, A. Okopień-Sławińska. Wrocław 1983. Zob. też P. Ricoeur, Proces metaforyczny jako poznanie, wyobrażanie i odczuwanie. Przeł. G. C e n d row s ka. Przejrz. T. D obrzyńs ka. „Pamiętnik Literacki” 1984, z. 2. - T. Dobrzyń s ka: Mówiac przenośnie... Studia o metaforze. Warszawa 1994; Od słowa do sensu. Studia o metaforze. Warszawa 2012. - Porwani przez przenośnie. O literaturoznawczych metaforach. Red. E. B alc e rza n, A. Kwiatkows ka. Słowo wstępne E. Balc erzan. Poznań 2007.

3 M. Stanis z, Od metody do metafory i z powrotem. Słowo wstępne. W: Światy i życie. Metafory poezji $w$ polskiej krytyce literackiej doby romantyzmu. Rzeszów 2019, s. 23-24 (tu w przypisach zob. też obszerny wykaz wieloaspektowych prac poświęconych metaforze przez badaczy reprezentujacych rozmaite dyscypliny).

$4 \quad$ Rozmaite aspekty poetyckiego warsztatu oświeceniowych literatów, w tym również stosowanej przez nich metaforyki przy podejmowaniu różnych tematów w licznych publikacjach prezentuje T. Ko s t- 
wano też problematykę żywiołów w poezji Franciszka Dionizego Kniaźnina. Przed półwieczem zagadnienie to zwięźle zasygnalizował Andrzej Krzysztof Guzek w rozważaniach na temat późnych utworów puławskiego autora, zawierających motywy burzy, wichury i pioruna, które podlegaja dynamizacji w apokaliptycznych wizjach „zagłady świata” ${ }^{5}$. Tę problematykę podjęła także Teresa Kostkiewiczowa w pracy dotyczacej naszej rodzimej poezji religijnej doby oświecenia, wskazując na frazeologię nawiązującą do żywiołów („wichrów, ciemnych chmur i burzy”) w oryginalnych lirykach Kniaźnina oraz w jego adaptacjach psalmów, łączacych religijne wątki Z odwołaniami do aktualnej sytuacji narodu i państwa ${ }^{6}$. Spostrzeżenia te autorka rozwinęła w studium poświęconym transcendentnej perspektywie liryki puławskiego twórcy, która to perspektywa ujawnia się przede wszystkim w wierszach inspirowanych Księga Psalmów, często adresowanych w tytule Do Boga i mających wyraźnie mesjanistyczne przesłanie ${ }^{7}$. Należy też przypomnieć, że liczne, zróżnicowane tematycznie wiersze tego poety przywołuje w celach porównawczych i kontekstowych Barbara Wolska przy rozpatrywaniu owej tematyki w książce poświęconej liryce Adama Naruszewicza ${ }^{8}$. Zanim powstanie analogiczne studium monograficzne o Kniaźninie jako poecie żywiołów, warto zwrócić uwagę na frekwencję wskazanego typu obrazowania w puławsko-sieniawskiej liryce tego autora, a także przybliżyć konkretne rozwiązania warsztatowe w wybranych wierszach o tematyce religijnej, ale też aktualnej, jak również w wątkach refleksyjnych utworów adresowanych do konkretnych postaci z epoki - utworów, w których Kniaźnin zastosował taką właśnie metaforykę. Zamiar zajęcia się tymi zagadnieniami wynika $z$ przekonania, że rozpoznania dotyczące poetyckich przywołań czterech pierwiastków, elementów bytu, a także celu, funkcji takich rozwiązań wzbogaca dotychczasową wiedzę o warsztacie twórczym puławskiego autora, o samym poecie, który stosował taki właśnie typ metafor, oraz o rzeczywistości pozaliterackiej, jaka skłaniała go do podejmowania konkretnych tematów ${ }^{9}$.

k i e w i c z ow a (m.in. Horyzonty wyobraźni. O języku poezji czasów oświecenia. Warszawa 1984; Polski Wiek Świateł. Obszary swoistości. Wrocław 2002; Mnemozyne i córki. Pamięć w literaturze polskiej drugiej połowy XVIII wieku. Toruń 2018). Interesujące spostrzeżenia dotyczące rozwiązań artystycznych stosowanych przez głównych poetów doby stanisławowskiej, w tym również w zakresie metaforyzacji wypowiedzi, zawierają analityczno-interpretacyjne „małe monografie” utworów w tomach zbiorowych: Czytanie Kniaźnina. Red. B. Mazurk ow a, T. Ch a ch uls ki. Warszawa 2010. - Czytanie Krasickiego. Red. T. Kostkiewiczowa, R. Doktór, B. Mazurkowa. Warszawa 2014. - Czytanie Naruszewicza. 1-2. Red. B. Wols ka, T. Ko s t ki e w i c zow a. Warszawa 2015. - Czytanie Trembeckiego. 1-2. Red. J. Sn opek, W. Kalis zew ski, B. Mazu rk ow a. Warszawa 2016. - Czytanie Karpińskiego. 1-2. Red. B. Mazu rk ow a, T. Ch a c huls ki. Warszawa 2017. Zob. też M. Pa tr o - K u c a b, Metafora, aluzja, eufemizm, koncept, żart... O tabuizacji ludzkiej seksualności w wybranych utworach Stanisława Trembeckiego. „Tematy z Szewskiej” 2015, nr 2.

5 A. K. G u z e k, Zamęt i harmonia. (O późnej liryce Franciszka Kniaźnina). „Poezja” 1970, z. 2, s. 11.

6 T. Ko s t ki e w i c z ow a, Poezja religijna czasów oświecenia $w$ Polsce. W zb.: Polska liryka religijna. Red. S. Sawicki, P. Nowa czyński. Lublin 1983, s. 135.

7 T. Ko s t ki e w i c z ow a, Transcendencja $w$ liryce Kniaźnina. W zb.: Motywy religijne $w$ twórczości pisarzy polskiego oświecenia. Red. ... Lublin 1995.

8 B. Wols ka, W świecie żywiołów, Boga i człowieka. Studia o poezji Adama Naruszewicza. Łódź 1995, passim.

9 Na tę zależność zwróciła już uwagę T. Do br zyń ska w studium Metafora jako narzędzie anali- 
W poetyckich deskrypcjach kreowanych przez Kniaźnina na potrzeby metaforycznego ujmowania wyobrażeń związanych z Bogiem i działaniami Najwyższego, w tym również przedstawień twórczych, które dotyczą aktualnych wówczas wydarzeń na polskiej i europejskiej scenie politycznej, z pokora zalecanych wejrzeniu Wszechmocnego, najliczniejsze są obrazy ognia oraz różnych elementów i zjawisk natury postrzeganych $\mathrm{w}$ przestrzeni powietrznej. $\mathrm{W}$ przypadku obu tych zakresów tematycznych wypowiedzi lirycznych $\mathrm{z}$ ciekawym obrazowaniem stykamy się w utworze adresowanym do Generała Ziem Podolskich jako marszałka Trybunału Głównego Litewskiego w roku 1781 - w odzie I 2 Do ks[iażęcia Ad[ama] K[azimierza] Czartoryskiego, marszałka Tryb[unału] Lit[ewskiego ${ }^{10}$. Zastosowana tu metaforyka, podobnie jak w wielu dziełach poetów baroku, zakorzeniona jest w realiach mitologicznych i chrześcijańskich. Instytucję sądowniczą nazywa Kniaźnin świątynią Temidy, greckiej bogini sprawiedliwości, prawa i wiecznego porządku. Wspomina też o mającej tragiczny finał historii Faetona, który nierozważnie powożąc rydwanem Heliosa, zagroził światu słoneczną pożogą. Drugi obszar przenośnych ujęć służy konkretyzacji Boga jako sędziego sprawiedliwego.

W związku z rzeczywistą funkcją trybunału jako najwyższego sądu apelacyjnego w dawnej Polsce Kniaźnin ukazał w utworze rzesze pokrzywdzonej biedoty, ciagnące do Grodna w nadziei na przychylny wyrok. Do władcy górnego Syjonu jako sprawiedliwego sędziego zanosi błagania upersonifikowana Rozpacz, a na to wołanie:

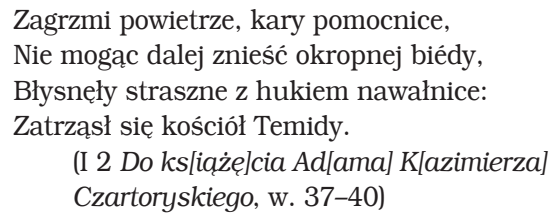

Zastosowane tu słownictwo o dużej ekspresji podkreśla destrukcyjną moc sił natury wytwarzajacych aure grozy, a tym samym wzbudzających strach. Sugestywnie wyrażone (także dzięki trafnie dobranym epitetom: nieszczęście jest „okropne” 'wielkie, ogromne', a gwałtowne burze - „straszne”, czyli 'groźne, niebezpieczne, przerażające'), silnie oddziałujące więc na percepcję wzrokowe oraz słuchowe efekty działania żywiołów ognia i powietrza (potencjalnie również wody ${ }^{11}$ ) potęguja

zy rzeczywistości. Martwa natura z pajęczyna w wierszu Stanisława Barańczaka (w: Od słowa do sensu, s. 116-117): „Metaforyzacja jest aktem poznawczym i formą ekspresji. Konstruując wyrażenie przenośne, podmiot mówiący wskazuje na rzeczy lub zjawiska podobne do zasadniczego przedmiotu swej myśli. [...] Równocześnie nie tylko wydobywa czy uwydatnia pewne aspekty owego przedmiotu [...], ale też odsłania siebie: swój tok myślenia, swoją wiedzę, kompetencję językową oraz swoje skojarzenia - skojarzenia, które są świadectwem osobistych doświadczeń i własnej aktywności albo ujawniają zależność od utartych schematów myślenia, utrwalonych w stereotypowych porównaniach i skonwencjonalizowanych wyrażeniach metaforycznych".

10 Utwory F. D. Kniaźnina cytowane są w pracy według ostatniej, autoryzowanej przez poetę wersji jego dorobku, zachowanej w przekazie rękopiśmiennym: Poezje [...] ręką własna pisane. T. 1, cz. 1. Bibl. Książąt Czartoryskich w Krakowie, rkps 2223 II.

1 Zob. S. B. Lind e, Stownik języka polskiego. Wyd. 2, poprawne i pomnożone. T. 3: M-O. Lwów 1857, s. 301 (hasło: nawat, nawała, nawałnica, nawatnośc). 
obraz Bożego gniewu z powodu cierpienia skrzywdzonych. Wzmocnienia wizualizacji tego ujęcia poeta dokonuje przez paralelny obraz, który wykorzystuje mitologicznie zakorzenioną metaforykę żywiołu ognia, tu - słonecznego żaru. Sam ogień nie podlega jednak deskrypcji, ale jest immanentnie zawarty w przywołanej historii o przejażdżce Faetona i jego śmierci od pioruna zagniewanego Zeusa. Dalsze partie utworu wzbogacają, jak się wydaje, symbolikę metaforyki żywiołu ognia zastosowanej w poetyckim obrazowaniu. Nawoływanie ludzi wyniosłych, zuchwałych i podłych do kajania się, przekonanie o niewzruszonej sprawiedliwości Wszechmocnego oraz płomień dopełniający zemstę - nieodparcie nasuwają skojarzenia $z$ historią miast biblijnych $z$ woli Jahwe strawionych pożogą.

Dotychczasowe przywołania metaforyczne ognia, będącego w wierszu znakiem Bożego gniewu, eksponują niszcząca, ale też oczyszczającą moc tego żywiołu, co tak sugestywnie wyrażali już poeci barokowi w wierszach o zróżnicowanej tematy$\mathrm{ce}^{12}$. Na jeszcze jeden kontekst interpretacyjny naprowadza strofa, która mówi o spełnieniu przez grodzieńska instytucję pokładanych w niej nadziei:

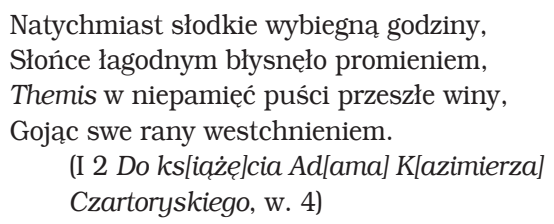

Wykorzystaną tu symbolikę solarną, wiążącą się z dobroczynnym oddziaływaniem słońca, blisko kojarzącego się z żywiołem ognia, można w szerokim rozumieniu łączyć z metafora Bożej łaski jako przejawu sprawiedliwości Pana, który wspiera ludzkie dążenia do jej poszanowania. Stąd przywołanie Temidy - postaci z innego obszaru kulturowego, również bardzo silnie inspirującego twórców - utrwalonej w zbiorowej świadomości dzięki wielowiekowej tradycji jako strażniczka uczciwego, prawego postępowania i wiecznego porządku.

Wydaje się, że dla takiego sposobu wykorzystania metaforyki żywiołów, a zwłaszcza sił natury związanych $z$ ogniem i powietrzem, $z$ jakim stykamy się w odzie I 2 Do ks[iążę]cia Ad[ama] K[azimierza] Czartoryskiego, marszałka Tryb[unału] Lit[ewskiego] i w innych wierszach poety, kluczowy jest jeden $\mathrm{z}$ utworów należących do biblijnej Księgi Dawidowej. Poetycka parafrazę owego liryku Kniaźnin zatytułował II 15 O wielkości Boga, w podtytule zaznaczając: Psalm 103 skrócony. W utworze tym wypowiedź bezpośrednio skierowana do Najwyższego wyraża pokorę człowieka wobec nieogarnionej wprost potęgi Pana oraz bezgraniczny zachwyt nad pięknem i harmonią żywiołów, pozornie sprzecznych z sobą nawzajem, ale w pełni podległych Jego woli:

O metaforyce ognia w dawnej poezji polskiej zob. m.in. A. Blu s i ew i c z, Ogień miłości. Z przemyśleń nad recepcja „Pieśni nad Pieśniami” w polskiej poezji barokowej. „Przegląd Powszechny” 1985, nr 7/8. - K. M row cew i c z, Dziwny świat, dziwna miłość, dziwna śmierć. „Teksty Drugie” 1994, nr 3. - K. O b r e m s ki, Niewidzialność Boga jako problem obrazowania poetyckiego. „Ogród” 1994, z. 1. - B. M a z u r k o w a, Ogień w obrazowaniu „Obleżenia Jasnej Góry Częstochowskiej”. W zb.: Czasy potopu szwedzkiego w literaturze polskiej. Red. R. O c i e c z e k. Katowice 2000. - M. Han u s i e w i c z, Pięć stopni miłości. O wyobraźni erotycznej w polskiej poezji barokowej. Warszawa 2004, passim. 


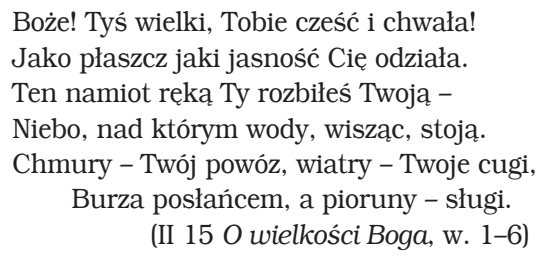

W zarysowanym tu obrazie, wyraźnie nawiązującym do aktu kreacji z Księgi Rodzaju, przywołane są przemożne siły natury: powietrze, ogień i woda. I chociaż występują tu również odniesienia do znanych człowiekowi realiów codzienności, poetycki obraz skomponowany $z$ wielu dynamicznych elementów jako pewna całość, obejmująca Stwórcę i Jego dzieło, przekracza w jakiejś mierze możliwości percepcyjne człowieka. Blask słonecznego światła porażający swą jasnością ludzki wzrok, powietrzna przestrzeń jako swoisty baldachim rozpostarty nad ziemią, deszcze unoszace się w górze - to charakterystyczne obrazy, rozpoznawalne w poetyckim, metaforycznym ujęciu, podobnie jak odwołanie w utworze do konkretnych relacji i funkcji społecznych. W dalszej części wiersza $z$ konkretnymi elementami otaczającej rzeczywistości łączy się również dynamiczne przedstawienie kreowania przez Boga przyrody nieożywionej, czyli żywiołu ziemi: „Skoroś rzekł słowo, a nieba zagrzmiały, / Pola w dół poszły, a ku górze skały” (II 15 O wielkości Boga, w. 11-12). Lekkością oraz migotliwością cechuje się obraz okrytej mgłami przepaści wypełnionej światłem i mrokiem ${ }^{13}$. Bardziej rozległych horyzontów wyobraźni wymaga natomiast wizualizacja przywołanych w utworze Bożych dzieł pozostających na usługach Wszechmocnego: powóz z chmur, zaprzęg $\mathrm{z}$ wiatrów oraz burze niczym posłańcy i słudzy do specjalnych poruczeń. Na podstawie tak upoetyzowanej prezentacji żywiołów nie sposób jednak wyobrazić sobie wizerunku Boga, chociaż autor wyraźnie sugeruje w wierszu Jego uosobiona postać - mowa tu o głosie i ręce Pana. Zgodnie $z$ biblijnym pierwowzorem Wszechmocny jest bliski, rozpoznawalny przez dzieło stworzenia, ale równocześnie nieokreślony - oglądany, ale niewidzialny. Wyobrażeń Najwyższego, kreowanych przy użyciu metaforycznych ujęć żywiołów, nie da się bowiem połączyć $\mathrm{w}$ utworze $\mathrm{z}$ jakąkolwiek osobową konkretyzacją. Percepcji człowieka dostępne są tylko Boże dzieła i skutki Jego woli, wyzwalające w czytelniku podziw dla potęgi Pana, który włada żywiołami. Jednoznacznie wyrażają to końcowe wersy adaptacji Psalmu 103:

\section{A ty, ma duszo, chwal wielkiego Boga, \\ Który gdy spojrzy, ziemia drży, i który \\ Ledwo tknie ręką - $\mathrm{z}$ dymem pójdą góry.}

(II 15 O wielkości Boga, w. 47-49)

W sposób bardzo zwięzły, a przy tym inny nieco niż tradycyjne ujęcia, odwołał się Kniaźnin do żywiołów ognia, powietrza i wody w wierszu skierowanym do Najświętszej Marii Panny. W pierwszej strofie utworu VI 9 Do Bogarodzicy przejaw hołdu dla Matki Boga stanowi wyrażone w formie apostroficznej przekonanie, że

13 Na operowanie kontrastami w utworach kierowanych przez Kniaźnina do Boga zwróciła już uwage Ko s t k i e w i c z o w a (Poezja religijna czasów oświecenia w Polsce, s. 129): „Sytuacja Boga i człowieka ukazana jest przez przeciwstawienie jasności i ciemności, dnia i nocy". 
wprost niemożliwa jest do określenia miara oddalenia przestrzeni powietrznej od głębi wód, metaforycznie oddająca dystans, jaki dzieli ludzi, w pełnym uniżenia pokłonie, od Królowej Nieba zasiadającej przy Wszechmocnym. W następnej strofie, zawierającej bardzo czytelne nawiązanie do proroctwa z Apokalipsy św. Jana, ciekawie wykorzystał Kniaźnin natomiast odwołanie do osadzonych w przestworzach, ale połączonych z żywiołem ognia ciał niebieskich, które emanują światłem (własnym lub odbitym):

\author{
Jaką̇̇̇ ozdobę dać możem \\ Na świetność Twojego czoła, \\ Której sam księżyc podnożem, \\ A gwiazdy świeca dokoła? \\ (VI 9 Do Bogarodzicy, w. 9-12)
}

Znany, łączony z Maryją obraz kobiety w koronie z gwiazd i księżycem pod stopami nie służy tu jednak - jak utrwaliło się w tradycji odczytań tego fragmentu biblijnej księgi - eksponowaniu szczególnego posłannictwa i rangi Matki Chrystusa, Jej udziału w dziele zbawienia. Kniaźnin wykorzystał bowiem migotliwe, cechujace się stonowanym blaskiem lunarne i astralne elementy natury związane $\mathrm{z} \dot{z} \mathrm{y}-$ wiołem ognia, aby w poetyckiej formule pytania retorycznego wyrazić niemożność ofiarowania Matce Boga daru, który w pełni wyraziłby hołd, jaki wierni winni Jej oddawać.

Żywiołom jako posłańcom Bożej woli poświęcony jest w części wiersz, w którym zwięźle zarysowana została scenka rozgrywająca się w lesie podczas burzy: „Grzmi niebo, szumi, łyska się i pali; / Kryją się zbójce, drżą mędrce zuchwali” (II 17 Piorun $z$ Thompsona, w. 1-2). Rozbrzmiewające w powietrzu gromy, szum wiatru i ogniste błyskawice przecinające nieboskłon - w przekonaniu (wspartym na wierze oraz ludzkim doświadczeniu) jednego $\mathrm{z}$ bohaterów - winny być oznaką Bożego gniewu, który dosięgnie występnych. Piorun zabija wszakże nie któregoś ze zbójców, lecz cnotliwą i niewinną Charynę. Kontekst, w jakim ukazana tu została rażąca moc niebieskiego ognia, spadającego z przestworzy w czasie burzy, odświeża metaforykę pioruna, dotyczy ona bowiem nie gniewu Wszechmocnego (w realiach mitologicznych - Zeusa/Jowisza), ale nieprzewidywalności Jego woli.

W okresie puławskim i w ostatnich latach pracy twórczej Kniaźnina w jego wierszach w powiązaniu z przedstawieniami żywiołów występuje w kilku wariantach obraz uśmiechniętego bądź też śmiejącego się Pana. W podniosłym liryku III 1 Do Lutni, odwołując się do kontekstu religijnego i zarazem do metapoetyckiego potencjału metaforyki ognia oraz powietrza, autor ukazuje moc poezji natchnionej Bożym duchem, która jest w stanie uśmierzyć gniew Najwyższego, wypalający występek pochodnią zemsty (,Serce przywrzałe do zbrodni [...] / Niechże się lęka pochodni, / Którą Bóg mściwy gotuje...”, w. 13, 15-16), i oddalić z serc ludzkich trwogę, strach przed rażącymi oznakami tegoż gniewu - wzbudzić natomiast nadzieję ${ }^{14}$. W przekonaniu Kniaźnina powołaniem poety i celem poezji jest więc głoszenie wielkości dobrotliwego Pana, a zatem również dziękczynienie Mu za dar łaski. Godna uwagi jest tu metafora pogody jako rozciagającego się na niebie uśmiechu. Wyraża on pełnię

14 Zob. rozważania J. T. P o k r zy w n i a k a poświęcone temu lirykowi w pracy Apokaliptyczna lutnia Kniaźnina. „Do Lutni” (w zb.: Czytanie Kniaźnina). 
łagodności oraz dobroci Najwyższego, a przede wszystkim łaskę, jakiej udziela On swemu stworzeniu („Dobroć na Twoje zmiękczona jęki / Uśmiech po niebie rozlała”, w. 19-20). W wypowiedzi skierowanej do poezji metaforyczny ekwiwalent takiej kreacji wizerunku Wszechmocnego stanowi wizja wyciszenia przestworzy - uspokojenia wichrów miotających powietrzem w czasie burzy i rozproszenia deszczowych chmur:

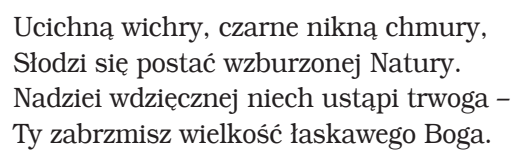

Dodajmy, że Kniaźnin w podobny sposób posłużył się metaforycznymi odwołaniami do żywiołów także w innych utworach o charakterze osobistym i zarazem metapoetyckim. Taka perspektywę przyjmuje poeta np. w odach Do Boga prezentujących bardzo bliską, intymną więź z Panem, która - jak wskazuje Kostkiewiczowa - mimo odczuwania przez człowieka małości i nędzy ożywiają: uparte dążenie do przekroczenia granicy, która oddziela go od Bóstwa, dojmujące pragnienie wzniesienia się ponad ziemskie, cielesne uwikłanie człowieka i wola pełnego zjednoczenia z Najwyższym „nie tylko w mistycznej kontemplacji, nie tylko w zwykłych okolicznościach codziennego życia, ale także w sferze osobowości i uczucia” ${ }^{15}$. W odzie I 1 Do Boga, już w pierwszym tomie Poezji (1787) otwierającym Liryki, w pokorze błagał Kniaźnin o ogień Bożej łaski, pobudzający władze rozumu, wzniecający siłę ducha i ożywiający poetyckie moce ${ }^{16}$. Tu bodaj najbardziej sugestywnie wyraził przekonanie, iź źródłem i zarazem dawcą natchnienia jest sam Bóg. Bezpośrednia konsekwencja takiej perspektywy to przeświadczenie, że pióro poety powołane zostało przede wszystkim do głoszenia chwały Pana. Trzy konteksty metaforyczne płomiennego żywiołu eksponuje wizja wzniesienia się za sprawą owego daru aż do niebieskiego firmamentu: „Zapal, a między gwiazd Twoich kołem / I ja ognistym zabłysnę czołem” (w. 23-24). Do tego wątku powraca Kniaźnin w tak samo zatytułowanej odzie VII 1 (inc. „Jakaż to nuża nade mną), mówiąc o niezwykłej mocy Bożego ognia: „Tknąłeś aż ogień i duch, i siła, / Aż oto latam po niebie” (w. 13-14). Kwestią do przemyślenia są tu inspiracje barokowymi ujęciami literackimi dualistycznej koncepcji natury ludzkiej. W drugim $z$ wymienionych wierszy Kniaźnin patrzy niejako z górnej perspektywy na stworzona przez Wszechmocnego piękną i wzniosłą przestrzeń powietrzną, gdzie harmonijnie współistniejące żywioły stanowią metaforę kreacyjnej mocy i mądrości Pana (w. 15-20).

Obraz śmiejącego się Boga, mający wszakże zupełnie odmienny charakter niż ten we wspomnianym już metapoetyckim liryku III 1 Do Lutni, zawiera również wiersz VI 8 Na wojnę turecka, dotyczacy konfliktu zbrojnego (1787-1792) między Rosją a potęga otomańska przy udziale Austrii. Jednoznacznie potępiając ekspansywną, kolonizacyjna politykę tych zaborców - zapewne także ze względu na spra- 
wy polskie - Kniaźnin ukazał oba europejskie mocarstwa jako drapieżne i bezwzględne harpie, które swój żer, czy też łup (,pastwę... swej dumy”, w. 4), chca umoczyć we krwi rzeszy walczacych poddanych. Scenerię wojny prowadzonej przez dwa mocarstwa z Turcją poeta dopełnił zwięźle zarysowanym, bardzo dynamicznym obrazem wielkiego wzburzenia, jakie opanowało żywioły ziemi i wody „pod orłów szponami” (w. 5), co stanowiło czytelne nawiązanie do godeł obu agresorów. W kontekście refleksji nad wydarzeniami rozgrywającymi się na międzynarodowej scenie politycznej Kniaźnin z nadzieją rozmyślał o sprawie polskiej, ufając Bożej Opatrzności. Wyrazem tego jest w wierszu właśnie wizja Boga, który „patrzy i śmieje się z góry" (w. 13), z dystansem przyglądając się ludzkiej pysze siejącej niepokój i zniszczenia, określonej tu metaforycznie jako „ślepe myśli wzniesienie” (w. 14). W takim przedstawieniu Najwyższego można, jak się wydaje, upatrywać realizację wariantu toposu deus ridens, którego dopełnienie stanowi metaforyczne ujęcie gniewu Boga zemsty, jaką ześle na winnych, oraz wolności, jaką obdarzy wierny lud, głęboko ufający w Jego sprawiedliwość:

\footnotetext{
Oto $\mathrm{z}$ wichrami zbierają się chmury,

Siejąc dokoła płomienie,

Burza wolności srogą zemstę budzi -

Strąci gmach pychy i podniesie ludzi.
}

(VI 8 Na wojnę turecka, w. 15-18)

Przewidywane przez poetę następstwa pychy tyranów - swoistą zapowiedź wyzwolenia się z ich przemocy, wyraża w wierszu bardzo plastyczna, odwołująca się do zmysłu wzroku metafora. Łączy ona dynamiczne elementy przestworzy (wichry, chmury) oraz współgrający z nimi żywioł ognia, który rozświetla nieboskłon w czasie burzy. Wziąwszy pod uwagę cel patronujący owym przedstawieniom, można mówić o kreacyjności zamysłu poety, który powoływał do myślowej egzystencji potencjalną, pożądana przez siebie rzeczywistość.

Śmiech Boga w utworze VI 8 Na wojnę turecka naznaczony został wyraźnym dystansem Pana wobec ziemskiego theatrum pychy, we wdzięcznym liryku XI 8 Do Konst[ancji] Dembowskiej ma natomiast inne, łagodne, ciepłe znamiona. W imieninowym wierszu poeta zastanawiał się, z czego ułoży bukiet dla pięknej, utalentowanej solenizantki w mroźny czas ${ }^{17}$, gdy „ojczyzna mdleje i kona” (w. 6) po utracie swych dzieci. W kontekście melancholijnej refleksji, zawierającej patriotyczne akcenty powiązane $\mathrm{z}$ odwołaniami do sytuacji politycznej państwa, nadzieję budzi metaforyczny obraz następstwa dnia po nocy - zwilżonych rosą słodyczy poranka, który przychodzi po zgaszeniu przez Wszechmocnego zbyt hardego oblicza słońca. W poetyckiej kreacji życiodajna moc wody uzyskała przewagę nad żywiołem ognia, mającym w tym ujęciu charakter potencjalny, ogień nie emanuje bowiem swą mocą na świat przedstawiony, a w procesie lektury nie oddziałuje na zmysł wzroku. Obraz świtu został jednak celowo przywołany ze względu na paralelną konstrukcję

17 Metaforyka kwietna była charakterystycznym elementem obrazowania w utworach imienionowych (często nazywanych bukietami), które apogeum swej popularności przeżywały w dobie stanisławowskiej. Zob. B. Wolska, B. Mazurkowa, T. Cha chulski, Oświeceniowa poezja imieninowa. W zb.: Wiersze imieninowe poetów z drugiej połowy XVIII wieku. Wstęp, wybór tekstów, oprac. ... Warszawa 2011, s. 15-84. 
metaforyczną, która zgodnie $z$ utrwalona już wówczas praktyką twórczą pozwalała zmiany zachodzące w naturze przenieść na rzeczywistość ludzką i rozpatrywać je $\mathrm{w}$ kategorii projekcji analogicznych zjawisk i wydarzeń. W tym przypadku dawała podstawę nadziei na Bożą opiekę nad ojczyzną i na nadejście poranka wolności.

Poetyckie obrazowanie z udziałem odwołań do dynamicznych sił natury Kniaźnin zastosował także $\mathrm{w}$ utworach, które łączą pierwiastki patriotyczne i religijne w kreowanych wizerunkach bohaterów lub adresatów wierszy okazjonalnych - nierzadko znanych postaci ze sfery publicznej. W liryku II $4 \mathrm{Na}$ śmierć ks[iążę]cia Aug[usta] Czartoryskiego ukazał nieugięta postawę wojewody wiernego Bogu, Kościołowi i ojczyźnie, stałość duszy Czartoryskiego i światłość jego umysłu oraz moralne męstwo przejawiające się $\mathrm{w}$ dawaniu odporu wszelkiemu złu. W tym celu poeta sięgnął po znaną i pojemną semantycznie metaforę wzniesionej ku niebu skały w czasie burzy, niewzruszonej wobec uderzających w nią morskich bałwanów i ognistych piorunów, które wypadają z chmur. W odzie XI 99 Na śmierć ks[iężnej] Czartoryskiej, kancl[erki] litewskiej zrealizował natomiast zamysł analogiczny do ujęcia, które Stanisław Trembecki zastosował w epicedium poświęconym jej zmarłemu 22 lata wcześniej (1775) mężowi Fryderykowi Michałowi Czartoryskiemu. Akcentując obywatelskie i patriotyczne rysy wizerunku kanclerza, powodów jego odejścia Trembecki upatrywał $\mathrm{w}$ tragedii pierwszego rozbioru ${ }^{18}$. Z kolei Kniaźnin przyczyny śmierci Eleonory Moniki z Waldsteinów Czartoryskiej (1797) połączył $\mathrm{Z}$ dojmującym żalem po klęsce trzeciego rozbioru, postrzeganego jako bolesny rezultat „srogiej burzy”, która rozpętała się nad Rzeczapospolita. W nawiązaniu do aktualnej, dramatycznej sytuacji politycznej kraju, zwracając się do zmarłej kanclerzyny, poeta konstatował w sposób stonowany emocjonalnie: „Usnęłaś Polski nieszczęściem zmęczona / I skołatana srogiej burzy ciosem” (w. 29-30). Optymistyczne akcenty łączą się tu nie tylko z perspektywą niebiańskiej nagrody za cnoty księżnej, ale także $z$ nadzieją na przychylny dla wspólnoty wyrok, jaki dusza zmarłej szczęśliwie odczyta z Bożej twarzy - na łaskawy dla narodu "promień z Opatrzności oka, / Co dla tej ziemi pomyślność wydarzy" (w. 33-34).

Pierwiastki religijne $z$ patriotycznymi ściśle spoił również Kniaźnin w powstałym na początku lat dziewięćdziesiątych XVIII wieku liryku dedykacyjnym XI 18 Ks/iężnej] Izab[eli] Czartoryskiej, ofiarując jej własne modlitwy $w$ rym ułożone. Pogodna aurę także $\mathrm{w}$ tym wierszu współtworzy metafora przychylnego dla cierpiących Bożego śmiechu, co wzmacnia kontrast między tym obrazem metaforycznym a piorunami przywołanymi w wierszu, także podległymi woli Pana. Ufność pokładana w Bogu okazującym podczas dziejowej burzy łagodne oblicze wiernemu ludowi „kotwicy... / na której oparł nadzieję” (w. 15-16) - stanowi podstawę optymistycznego wejrzenia w przyszłość projektowaną przez poetę ${ }^{19}$. Metaforą łaski Najwyż-

Zob. Sz. P. Dąbrowski, Ostatnie pożegnanie i pochwała męża stanu: „Na śmierć ksią̇ęcia Czartoryskiego, kanclerza w. W. Ks. Lit.”. W zb.: Czytanie Trembeckiego, 2.

19 Nadzieja na szczęśliwą, z Bożą pomoca, przyszłość kraju i narodowej wspólnoty, tak silnie rozbrzmiewająca w tym liryku oraz w wielu innych późnych wierszach Kniaźnina, choćby w odzie XI 1 Na rewolucja 1794 (zob. B. M a z u r k ow a, Bóg, cnota i nadzieja $w$ dziejowej burzy Rzeczypospolitej. „Na rewolucja 1794”. W zb.: Czytanie Kniaźnina), szerszym echem odbiła się w polskiej poezji powstałej po ostatecznym upadku państwa. Zob. też P. Ż bi kow s ki, „...bolem śmiertelnym ściśnione mam serce..." Rozpacz oświeconych u źródeł przełomu w poezji polskiej w latach 1793-1805. 
szego dla zniewolonego narodu jest tu również sytuowany w niedalekim czasie, a ujęty w wizji mającej znamiona proroctwa, obraz wyrażonych przez "godowe wieńce" szczęścia oraz pomyślności radujących matkę-ojczyznę i jej dzieci. W poetyckim przedstawieniu ten zbiorowy entuzjazm wyzwala ogień, który nie ma mocy niszczącej, nie pali, ale grzeje - to będące metaforą Bożej przychylności „nowe słońce”. Ono bowiem w owym profetycznym widzeniu twórcy „na wyzwoleńcach / Słodkim uczuciem twarze roznieci” (w. 21-22) i w atmosferze szczęścia narodowej wspólnoty „blaskiem olśni dzień złoty” (w. 26). W aurze rozświetlonej dobrocia Wszechmocnego, opromienionej ciepłem Jego miłości osadził poeta proroczą wizję odzyskania wolności przez Polaków.

Optykę patriotyczno-polityczną i religijną Kniaźnin połączył również w kilku utworach zatytułowanych Do Boga. Powierzył w nich Wszechmocnemu troski i lęki związane $\mathrm{z}$ losami kraju oraz narodowej zbiorowości, z którą się utożsamiał i której racje reprezentował w poetyckich rozmowach $z$ Panem ${ }^{20}$. Do władzy Najwyższego nad żywiołami autor odwołał się w bardzo silnie nacechowanym emocjonalnie, podniosłym monologu lirycznym rozpoczynającym się pełnym determinacji apelem: „Ratuj, o Boże, i podnieś ducha / Światłości Twojej promieniem!” (X 17 Do Boga, w. 1-2). Poeta wygłasza w utworze błagalną prośbę o światło Bożej łaski, które obnażając „zuchwałe błędy” ludzkie oraz mroczność umysłów, umocni osłabłe w narodzie siły ducha i wiary. Wołaniu temu przydaje dramatyzmu i eksponuje go zabieg znamienny dla warsztatu Kniaźnina w tym okresie: kontrast, tu między jasnością blaskiem daru Najwyższego - a czernią win, powodowanych przez pychę kojarzoną z mrokiem ludzkich myśli i serc. Błaganiu o łaskę towarzyszy w utworze pełna pokory i poczucia winy prośba o zasłużoną karę, która unicestwi, ukróci szerzące się we wspólnocie nieposłuszeństwo i samowolę, przywracając tym samym pokój ludzkim sercom oraz tryumf Bożej chwały. Wtórujące owemu wołaniu poczucie zagrożenia bytu zbiorowego wyraził poeta w metaforycznym obrazie zbudowanym $z$ elementów i zjawisk przynależących do sfery powietrznej, z trwogą konstatując: „Znikają w chmurach nadziei zorze" (w. 13). Właśnie w takim kontekście, motywowanym lękiem o los wspólnoty, siegga po niezwykle dynamiczne elementy natury, nadając im znamiona metafory rozgrywającego się w rzeczywistości dziejowego dramatu kraju, ale również metafory zła, fałszu oraz zbrodni, które wraz z upadkiem ducha zawładnęły ludzkimi sercami, a także umysłami. Tak poeta prosił i jednocześnie sławił Wszechmocnego, ufając w Jego moc i ratunek:

\footnotetext{
Każ burzy, niechaj nie huczy morze,

I wiatrom, niechaj nie dmą z północy,

A zaraz wielka Twym słowem, Panie,

Spokojność stanie.

Ukaż twarz swoję i prawdę jasną,

Aby nad ziemią władzom świeciły,
}

Wrocław 1998. - M. Nale p a, Rozpacz i próby jej przezwyciężenia w poezji porozbiorowej (17931806). Rzeszów 2003. - J. Kow a l, „W sercu Polaka żyj, nadziejo święta!” O kategorii nadziei w polskiej poezji porozbiorowej lat 1793-1796. „Zeszyty Naukowe PWSZ w Sanoku” 2009, nr 6.

20 W charakterystyce tej grupy liryków $z$ odwołaniami do żywiołów uwzględnione zostały obserwacje zawarte w analityczno-interpretacyjnych rozważaniach Kostkiewic zowej w studium Transcendencja w liryce Kniaźnina (s. 209-214). 


\section{Zniknie obłuda i ognie gasna, \\ Które czczym duchem świat zapaliły. \\ Nie rozeznajem cnoty od zbrodni \\ Bez tej pochodni!}

(X 17 Do Boga, w. 15-24)

Poeta, błagając Najwyższego o uciszenie rozszalałych żywiołów, o ugaszenie pożogi trawiącej świat, a zatem o przywrócenie równowagi i pokoju w życiu zbiorowości (do której należy) przez obdarowanie jej wolnością, wyraża także niezachwianą wiarę w potęgę i moc pochodni Bożej prawdy, w dobroć i miłosierdzie Pana. Wezwania kierowane do Niego współtworzą w wierszu metaforyczną wizję przemożnych, rozszalałych zjawisk natury reprezentujących żywioły powietrza i wody - burzy, wiatru i sztormu - jako sług i zarazem posłańców Wszechmocnego, całkowicie podległych Jego woli i rozkazom ${ }^{21}$. Warto przy tym zauważyć, że przywołane tu przejawy żywiołu ognia mają wymiar zarówno realny, jak i metaforyczny - w drugim przypadku sa znakiem łaski Pana.

Także w liryku VII 14 Do Boga (inc. „Kędyż te duchy, co pełne wilgoci”) poeta w dynamicznym obrazie ukazał władzę Pana nad żywiołami powietrza, ziemi i ognia. Przejawy ich pokory wobec Jego mocy uzyskały w liryku znamiona metaforycznej wizji kornego hołdu dla Najwyższego: „Łysnąłeś! Ziemia Twym gromem przejęta, / Korzą się lasy, a góry zadrżały" (w. 25-26). W tym też duchu kierowana jest w utworze prośba do Boga o zesłanie ognistej pomsty „Na wiarołomce, sprosne winowajce, / Na niewdzięczniki i zdrajce!" (w. 29-30).

Bardzo czytelne uwarunkowania polityczne ma dynamiczne obrazowanie żywiołów w jednym $z$ najlepszych wierszy obywatelskich Kniaźnina - w okolicznościowej odzie VI 10 Do Zgody. Na sejm 1788. Nawoływania do powszechnej zgody, do pojednania trzech antagonistycznych stronnictw sejmowych, wsparł autor w utworze wizja straszliwej kary, jaka sprawiedliwy Władca nieba i ziemi zsyła przez ognistego anioła na okrutnych tyranów, bezprawnie gnębiących wolne narody ${ }^{22}$. Równie poruszające jest w wierszu wyobrażenie upersonifikowanej Zgody, która w kosmogonicznej wizji poety uzyskała niezwykłe znamiona, nadane jej przez Boga ${ }^{23}$. To Zgoda bowiem harmonijnie spaja wszystkie elementy stworzenia - także sprzeczne

żywiołów, Boga i człowieka, s. 40, 57.

Zob. M. Marcin kow s ka, Wizja groźnych i destrukcyjnych sit natury $w$ dawnych modlitwach. W zb.: Światy oświeconych i romantycznych. Doświadczenia, uczucia, wyobraźnia. Red. B. Maz u r k ow a. Katowice 2015, s. 73-75.

Ukazany w wierszu czas Bożej zemsty (w. 5-10) w sposób czytelny nawiązuje do rozdziału 19 (wersety 11-16) Apokalipsy św. Jana, zatytułowanego Zagłada wrogich narodów. Pierwsza walka zwycięskiego słowa (zob. Objawienie św. Jana. W: Biblia $w$ przekładzie Księdza Jakuba Wujka z 1599 r. Transkrypcja typu „B” oryginalnego tekstu z XVI w. i wstępy J. F r a n k ow s ki. Warszawa 1999). Tam bowiem mówi się o wypełniającym Słowo Boga aniele, który ma oczy jak płomień ognia. Kniaźnin poetycko przetworzył wyraziste realia wyzyskane w tym frenetycznym obrazie: szatę $z$ krwi i ostry miecz uderzający we wrogie narody. Wymienione elementy wizualne pełnią w wierszu funkcję aluzji nowotestamentowej, podobnie jak „rózga żelazna” uwzględniona w sugestywnej deskrypcji. Według wskazanego źródła (Ap 12,5) właśnie rózgą (laską) żelazną będzie pasł wszystkie narody mężczyzna, którego porodzi Niewiasta. 
ze sobą nawzajem żywioły - i sprawuje nad nimi pieczę. Prośbę o złączenie narodu z królem i króla z narodem skierował zatem twórca właśnie do upersonifikowanej Zgody - „świata mistrzyni”, której siłom i opiece już u początków istnienia wszechświata sam Bóg miał powierzyć dzieło stworzenia:

\section{[...] bryłę wszech rzeczy \\ $\mathrm{W}$ pierwszym wiszącą zamęcie Jasnymi wiecznie rozgwiaździła koły, Sporne zwabiwszy ku sobie żywioły.}

(VI 10 Do Zgody, w. 21-24)

Kosmogoniczną wizję Kniaźnin zarysował również w utworze VI 17 Karlsbad, zawierającym, stosunkowo rzadko stosowane przez niego, metaforyczne ujęcie żywiołu ziemi jako dynamicznego elementu natury powołanej do istnienia przez Kreatora. W wierszu tym utrwalił refleksje nad Bożym „rozruchem świata”, do jakich skłoniły go obserwacje naturalnego krajobrazu modnego wówczas uzdrowiska z wodami leczniczymi. Poeta ukazał w wierszu działania Boga, który przezwyciężył zamęt rozszalałych żywiołów, a następnie rozdzielił je i każdemu wyznaczył właściwe miejsce w przyrodzie, powołując tym samym poszczególne sfery świata:

\footnotetext{
Kiedy w okropnym żywiołów rozmęcie Waga tej ziemi szukała swej miary, Ogień z powietrzem gdy na jej przejęcie Rozdzielał wody i cisnął w pieczary,

(VI 17 Karlsbad, w. 7-10, 14-16)

$\mathrm{W}$ jednym szeregu $\mathrm{z}$ innymi żywiołami autor wymienił również ziemię w liryku II 18 Do Piotra Borzęckiego. Wskazał konkretne sfery świata i zamieszkujące je byty jako potencjalne tematy swej twórczości: „Celem tej pracy powietrze, / Ziemia i niebo, co świeci, / Pełza i leci" (w. 6-8). Poetyckiemu obrazowaniu żywiołu ziemi służą też nawiązania do biblijnego aktu kreacji w odach: III 10 Do Ignaclego] Cieplińskiego oraz V 4 Do ks[iążęcia Ad[ama] Jerz[ego] Czartoryskiego. Wiosna z Wirgilego. Najbardziej natomiast upoetyzowaną wizję żywiołów powołanych przez Wszechmocnego do istnienia zawarł Kniaźnin w Hymnie do Boga (V 1). Wyraził tu podziw i hołd dla kreacyjnych mocy Najwyższego, na którego słowie „wiszące okręgi / Niezgasłym siebie ogniem zapaliły” (w. 21-22). Nawałnice deszczu unoszace się na czarnych skrzydłach burzy oraz błyskawice, co „Hucznym strzeliły gromem” (w. 46), są dla poety obrazem Bożej potęgi, „której się bać trzeba” (w. 47). Zraszający ziemię życiodajny żywioł wody, mający w sobie moc „niebieskiego żywota”, to piękna metafora Bożej łaskawości, a barwny łuk tęczy na niebie to - jak poeta wyznaje Stworzycielowi - „Hasło przyjemne Twej wiecznej dobroci” (w. 54). W obliczu sugestywnie ukazanych, urzekających wizji podkreśla Kniaźnin najgłębszą, z otchłani kierowaną ku niebu pokorę wobec potęgi Bożego majestatu i piękna świata jako obrazu doskonałości Wszechmocnego. Stąd pragnienie poety, aby osobiście wyrazić wdzięczność za te dary, całkowicie poddać się woli Pana i zanurzyć się na wieczność w cieple ognia Jego miłości. 
Z metaforyką żywiołów stykamy się także, aczkolwiek znacznie rzadziej i zasadniczo przy udziale mniej dynamicznych elementów poetyckiego obrazowania, w wierszach Kniaźnina podejmujących wątki refleksyjne. Wprawdzie w lirykach tych twórca wielorako odwołuje się do Bożej instancji, lecz nie mają one stricte religijnego charakteru. W odzie II 8 Do ks[iędza] Fab[iana] Sakowicza (inc. „Otoż labirynt niezmierny”) rozterek towarzyszących namysłowi poety nad możliwościami poznania świata i rządzących nim praw, ustanowionych przez Boga, dopełniają złowrogie obrazy zagniewanej natury, burzącej się przeciwko próbom, jakie „Niepewni onej badacze / I sprzeczni z sobą tajemnic onej tłumacze" (w. 7-8) podejmują, aby siłą wydrzeć jej odwieczne tajniki. Na te potrzeby Kniaźnin wykorzystał w swoim utworze stosowana już wcześniej metaforykę żywiołu ziemi i powietrza, modyfikując jedynie jej elementy w celu wzmocnienia efektów dla wywołania uczucia lęku. Stąd projektowany obraz ziemi, która drżeniem okazuje gniew i burzy ład budowany przez harmonijne współistnienie przestrzeni powietrznej oraz sfery nieba. Wspomniane sa także jęki wydobywające się $z$ „mogił okropnych”.

W różnych wariantach Kniaźnin przywoływał również żywioły, kreśląc poetyckie wizerunki adresatów lub bohaterów swoich wierszy. W początkowej części ody IV 2 Do ks[iędza] Fab[iana] Sakowicza (inc. „Odeszła chmura, wylawszy deszcze”) dynamiczne zjawiska natury, w czasie burzy wywoływane przez trzy żywioły - zwiastuny wielorakich zagrożeń zewnętrznych - stanowią tło, z którym wyraziście kontrastuje nacechowane spokojem oblicze adresata wiersza. Zwracając się do przyjaciela, Kniaźnin konstatował:

\author{
Niech grożą zbrodni zemstą natury \\ Ogień, powietrze i woda. \\ Na twoim czele, co nie zna chmury, \\ Jednaka zawsze pogoda.
}

(IV 2 Do ks[iędza] Fab[iana] Sakowicza, w. 5-8)

Pogodna, emanująca spokojem twarz odzwierciedla w utworze czyste, szczere serce, łagodne usposobienie oraz wewnętrzną harmonię proboszcza Czarnawczyc, postrzeganego przez poetę jako uosobienie stoickiej cnoty, ale też jako człowiek pełen „dowcipu i wdzięku”, na co wskazuje przywołana opowieść o Arystofanesie i mitologicznych Gracjach.

Warto również za Wolską zwrócić uwagę na szerokie zaplecze filozoficzne przywołań żywiołów „w pełnych rozmachu przedstawieniach Natury "w powszechnym ruchu" w wierszach prezentujących kosmogoniczne ujęcia sfer świata, takich jak wspomniane już utwory zatytułowane Do Boga oraz liryki okolicznościowe - Karlsbad, Do Zgody czy Do Piotra Borzęckiego ${ }^{24}$.

Metaforyczne przedstawienia żywiołów w przywołanych dotąd realizacjach poetyckich, w większości pozbawione znamion utartej frazeologii, bardzo korzystnie zaświadczają o wyobraźni twórczej Kniaźnina, o jej kreacyjnych aspektach, o prorockim duchu zwłaszcza późnej liryki poety, a także o jego duchowej i emocjonalnej wrażliwości i dynamicznym charakterze rzeczywistości, jaka postrzegał on wokół 
siebie - dramatycznej sytuacji dziejowej kraju i osobistego dramatu, który przed połową 1796 roku pogrążył go w mroku obłędu. W świetle ustaleń badawczych Kostkiewiczowej te dwie sfery ściśle łączą się bowiem ze sobą w stosunku poety do Boga i w relacji do zbiorowości, której czuł się reprezentantem i wyrazicielem. Także w utworach spoza obszaru religijnego Kniaźnin w sposób bardzo sugestywny i celowy wykorzystał metaforykę żywiołów, głównie ognia i powietrza, a w kilku realizacjach również ziemi. Nie traktował tego typu ujęć jako poetyckich ozdobników, lecz jako środki wyrazu najpełniej oddające różne intencje i niuanse myśli, które kierował do Wszechmocnego. Za pomoca owych środków ogarniał otaczająca go rzeczywistość trudnego czasu, a także potwierdzał więzi łączące go z konkretnymi osobami i wydarzeniami. Tym samym stosowana przez Kniaźnina metaforyka żywiołów ma walory nie tylko artystyczne, ale też w szerokim zakresie poznawcze.

Zarówno stan badań nad omawianym zagadnieniem, $\mathrm{z}$ konieczności pokrótce zasygnalizowany, jak i zaprezentowany materiał wybrany $\mathrm{z}$ warsztatu twórczego Kniaźnina skłaniają do bliższego zajęcia się wskazaną problematyką po dokonaniu pełnych rozpoznań w jego poezji z myślą o przygotowaniu obszerniejszego, monograficznego studium. Przy czym pod uwage należałoby wziąc również wczesne wiersze $\mathrm{z}$ okresu warszawskiego, gdzie w kreacjach świata przedstawionego, bohaterów i postaci wypowiadających się odwołania do czterech żywiołów współtworzących materię wszechświata dopełnione są, a nierzadko zdominowane przez obrazowanie jeszcze jednego, niezwykle ważnego elementu - który jest, jak stwierdził Kniaźnin w Erotykach, „piątym świata żywiołem” (IX 34 Refleksja, w. 2) - miłości, ukazanej w rozlicznych odsłonach i odcieniach emocjonalnych.

Abstract

BOŻENA MAZURKOWA University of Silesia, Katowice

ORCID: 0000-0003-3546-6583

\section{METAPHOR OF ELEMENTS IN FRANCISZEK DIONIZY KNIAŹNIN'S LYRIC POETRY}

The author of the article focuses on the artistic shape and the functions of elements' metaphorical images in the poems by Franciszek Dionizy Kniaźnin, one of the most important lyrist of the Polish Enlightenment. Employing the means of expression discussed in the paper, the poet attempted to fathom the difficult reality he was surrounded by, but also confirmed his connections with specific people and occurrences. The analysis of the metaphorical images of the elements in Kniaźnin's pieces reveals his deliberate and intentional use of the representations, mainly of fire and air, devoiding them of their ordinary phraseology. The analysed metaphors well support the view of Kniaźnin's creative imagination, its creative aspects, as well as his spiritual and emotional sensitivity, alongside of the dynamic character of the reality he perceived around him. 